\title{
Nocturnal position in the Panamanian Golden Frog, Atelopus zeteki (Anura, Bufonidae), with notes on fluorescent pigment tracking
}

\author{
Erik D. Lindquist ${ }^{1,2}$, Scott A. Sapoznick ${ }^{2,3}$, Edgardo J. Griffith Rodriguez ${ }^{4}$, Peter B. \\ Johantgen $^{5}$, and Joni M. Criswell ${ }^{6}$ \\ 1 Department of Biological Sciences, Messiah College, One College Avenue, Grantham, Pennsylvania 17027, USA. \\ E-mail: quist@messiah.edu (present address). \\ 2 Department of Natural Sciences and Mathematics, Lee University, Cleveland, Tennessee 37311, USA. \\ 3 Division of Biological Sciences, University of Missouri, Columbia, Missouri 65211, USA. E-mail: sashw6@mizzou.edu. \\ 4 Departamento de Zoología, Universidad de Panamá, Ciudad de Panamá, Panamá. E-mail: virolasboy01@yahoo.com. \\ 5 Shores Department, Columbus Zoo and Aquarium, 9990 Riverside Drive, P.O. Box 400, Powell, OH 43065, USA. \\ E-mail: pete.johantgen@columbuszoo.org. \\ ${ }^{6}$ Department of Evolution, Ecology and Organismal Biology, The Ohio State University, Columbus, Ohio 43210, USA. \\ E-mail: criswell.13@osu.edu.
}

\begin{abstract}
Nocturnal position in the Panamanian Golden Frog, Atelopus zeteki (Anura, Bufonidae), with notes on fluorescent pigment tracking. The endangered Panamanian golden frog, Atelopus zeteki, is a stream dweller of middle elevation rain forests of the Panamanian isthmus. In order to better understand this species for conservation, we set out to determine the nocturnal whereabouts of this diurnally active animal. It was expected that adult males and juveniles might occupy different nocturnal microhabitats based on differences in size, coloration and patterning. Findings presented here demonstrate that adult males climb significantly higher than juveniles at night and that movement distances to final resting positions also significantly differed. This change in diurnal and nocturnal position in adult males may be related to predator vigilance and avoidance. Lastly, this study demonstrated that individual rain forest amphibians can be successfully tracked over short to moderate distances in humid to wet environments using fluorescent pigments.
\end{abstract}

Keywords: Anura, Bufonidae, Atelopus zeteki, aposematic coloration, behavioral ecology, climbing, fluorescent pigment.

Received 4 October 2006.

Accepted 13 February 2007.

Distributed June 2007. 


\begin{abstract}
Resumen
Posición nocturna en la rana dorada de Panamá, Atelopus zeteki (Anura, Bufonidae), con notas respecto al rastreo con el uso de pigmentos fluorescentes. La rana dorada de Panamá, Atelopus zeteki, una especie en peligro de extinción, habita en los ríos de los bosques lluviosos de mediana elevación del istmo panameño. Con el propósito de conocer mejor ésta especie para su conservación, decidimos determinar los sitios de descanso nocturno de estos animales, los cuales se caracterizan por ser activos durante el día. Suponíamos que los machos adultos y los juveniles podrían ocupar micro hábitat distintos durante la noche, basándose en las diferencias en tamaños y patrones de coloración. Los resultados presentados aquí demuestran que, al caer la noche los machos adultos trepan significativamente más alto que los juveniles y que la distancia de estos movimientos desde el punto inicial hasta la posición final de descanso es también significativamente diferente. Estos cambios de posición durante el día y la noche de los machos adultos podrían estar relacionados con una conducta antipredatoria. Finalmente este estudio demuestra que con el uso de pigmentos fluorescentes es posible rastrear anfibios en los bosques lluviosos con habitates húmedos a mojados a través de distancias cortas a moderadas de manera exitosa.
\end{abstract}

Palabras clave: Anura, Bufonidae, Atelopus zeteki, coloración aposemática, comportamiento de subir, ecología del comportamiento, pigmento fluorescente.

\section{Introduction}

The Panamanian golden frog, Atelopus zeteki Dunn (1933), is a bufonid that inhabits mountain streams of the Cordillera Central in rain and cloud forests in western-central Panama (Savage 1972, Cocroft et al. 1990, Lindquist and Hetherington 1998a). Although historically abundant, most golden frog populations have become extirpated or currently are in decline due to excessive collection and habitat destruction (pers. obs.). In response to these pressures in 1975, this species was listed under endangerment Appendix I under the CITES (CITES 2004). In the past ten years, the fungal pathogen Batrachochytrium dendrobatidis has caused the extinction of many Atelopus species (Lips et al. 2005, 2006, Johnson 2006, Pounds et al. 2006). Within three months of this manuscript's submission, each of our study populations had been effectively driven to extirpation (Lips et al. 2006, pers. obs. EDL,
EJGR). Life history and ecological data is largely limited to descriptive work on this species (Savage 1972, Miller 1987, Lindquist and Hetherington 1998a). Acoustic and visual communicative behaviors have been reported by Lindquist and Hetherington (1996, 1998b), but knowledge of territoriality, ritualized agonistic displays, and microhabitat use remain incomplete. Moreover, most data have been gathered on males, as streamside sex ratios strongly favor males during the majority of the year. Diurnally, adult males have been observed on the ground alongside or upon rocks and logs in or near streams. Typical diurnal activity of males includes foraging, calling, semaphoring, and sporadic agonistic encounters (Lindquist \& Hetherington 1996, 1998b, pers. obs,). Casual observations have indicated that adult male and, on occasion, female golden frogs climb and perch on vegetation near the stream banks at night (Miller 1987, pers. obs.). The diurnal whereabouts of both females and juveniles have 
been difficult to establish beyond occasional stream and trail sightings during reproductive migrations and metamorphic emergence respectively (pers. obs.). It has been reported in this and other Central American Atelopus species that females and juveniles predominantly seek cover under forest canopy and/or in rock crevices along stream banks (Crump 1986, G. Angehr pers. com.), although no studies have been able to confirm this. Yet the authors regularly have seen cryptic young in the daytime and nighttime upon moss-covered rocks bordering streams.

The study described here set out to establish and quantify the nocturnal whereabouts of adult males and juveniles, as compared to their diurnal locations, and to determine if there was a difference between age cohorts with respect to perching position. Movements of adult females are not reported in this study due to their scarcity along the stream study sites (only three were encountered during the study period).

The study discussed here employed pigment tracking on a rain forest frog species. We set out to test whether adult males climb to higher nocturnal roosting sites and cover greater distances to do so than do juveniles as witnessed by casual observation. Establishing whether or not these differences actually exist could offer insights on potential selection pressures and/or other aspects of the species' biology. We expected no difference in cohort movement distance between population sites. Lastly, the study set out to determine whether any difference in final nocturnal perching positions exists with respect to the stream edge.

\section{Materials and Methods}

During study trips taken in March 2001, January 2002, July 2002 and January 2003, we visited golden frog populations in the Parque Nacional General Omar Torríjos - El Copé, Coclé Province, Panamá (PNGOT, hereafter) and a tributary to the Río Chame near Sorá, Panamá Province, Panamá (Chame, hereafter).
The populations under investigation have been identified as two unique evolutionary significant units (ESU) and therefore the authors used statistical treatments that included both pooled and unpooled site data to clarify differences and similarities (Zippel et al. 2007). Individuals were assigned as juvenile $(<28.2 \mathrm{~mm})$ or adult (>36.2 $\mathrm{mm}$ ) by Snout-Vent Length (SVL). The absence of this size class along streams is corroborated by data gathered in a two year study on the species (Lindquist et al. in prep.; Griffith pers. obs.). Over the course of the study period, 9 adult males (SVL $0=43.2 \mathrm{~mm}$; range $=39.5-46.7 \mathrm{~mm}$ ) and 28 juveniles (SVL $0=$ $16.3 \mathrm{~mm}$; range $=9.9-26.8 \mathrm{~mm}$ ) from PNGOT and 13 adult males (SVL $0=41.8 \mathrm{~mm}$; range $=$ $36.2-44.8 \mathrm{~mm}$ ) and 10 juveniles (SVL $0=22.7$ $\mathrm{mm}$; range $=15.2-28.2 \mathrm{~mm}$ ) from Chame were tracked.

Thermoplastic fluorescent pigments (JST300 series) were purchased from the Radiant Color Company (Richmond, CA, USA) and placed in $250 \mathrm{ml}$ plastic containers. These pigments range in particle size from 2 to 4 ìm and are capable of indefinite storage. Five colors were used in this study (JS-CH3020, JSGR3011, JS-OY3022, JS-OR3034, and JS-PK 3017). Pigment containers were kept in individual Ziploc ${ }^{\circledR}$ freezer bags to reduce cross contamination in the field. Dual-tube fluorescent Coleman ${ }^{\circledR}$ lanterns were used for pigment illumination. Lanterns were modified by outfitting them with black fluorescent light tubes (long wavelength UV BLB; $365 \mathrm{~nm}=$ dominant ë) and inserting three mirrored glass panels inside the bulb case to allow unidirectional light projection and to enhance light intensity.

Individual animals were captured by hand between 13:00 and 17:00 h. Subjects had pigment applied within 90 min of capture and were released immediately afterward. Pigment application consisted of grasping an individual dorsolaterally while placing much of the venter into the fluorescent powder held in a plastic container. Pigment contact included ventral palmar, plantar, and abdominal surfaces. Once 
sufficiently applied, the animal was released alongside the stream and the initial release area was marked with fluorescent vinyl flagging to indicate where to return at night for tracking. To prevent cross contamination of trails, frogs were powdered away from the site of release, and placed at the location of capture. Investigators returned to stream sites after dark (ca. 19:00 h) to track pigmented individuals.

Once returning to each release site, the pigment trail was then followed under black light until the tracked subject was found. Pigment residues left behind from contact with substrate were remarkably robust. Once the subject was found, nylon twine was overlaid along the pigment trail (straight line distance between tracks) and measured to obtain a total distance tracked (TDT) in $\mathrm{m}$. Fluorescent colored twine was used to permit better visibility under black light illumination of pigment tracks. Vertical perch positions $(Y)$ of individuals were noted by measuring the perpendicular distance from the final nocturnal perching location to the substrate immediately below. If an individual ( $n=3$, all juveniles) was tracked to a burrow, a vertical distance of zero was entered (see Figure 1). Likewise, horizontal perch positions $(X)$ of individuals were noted by measuring the distance from the final nocturnal location to the nearest stream edge. If an individual was found at a location at or above the stream, a horizontal distance of zero was entered. Afterward residual pigment was rinsed from recovered frogs. Each individual was tracked once to avoid pseudoreplication error and to determine an estimate of $T D T, Y$, and $X$ for the two age classes identified in this study. Statistical analyses and calculations in this study used the VassarStats Web Site for Statistical Computation (Lowry, 2004).

\section{Results}

\section{Vertical perch position}

Findings from our study demonstrated that adults and juveniles differentially utilize nocturnal microhabitats with respect to vertical distance from the substrate. Vertical distance from substrate $(Y)$ was significantly greater in adult males $(0=0.96 \mathrm{~m}$; $\mathrm{sd}=0.68)$ than in juveniles $(0=0.14 \mathrm{~m}$; sd $=0.23)(\mathrm{P}=<0.0001$, $\mathrm{z}=4.85, \mathrm{n}_{\text {adult }}=22, \mathrm{n}_{\text {juvenile }}=38$; Mann-Whitney $\mathrm{U}$ test, one-tailed; data from pooled sites). Within each population, detected differences in $Y$ were highly significant at PNGOT ( $\mathrm{P}=$ $0.0002, \mathrm{z}=3.54, \mathrm{n}_{\text {adult }}=9, \mathrm{n}_{\text {juvenile }}=28$; MannWhitney $\mathrm{U}$ test, one-tailed) and at Chame ( $\mathrm{P}=$ $0.0110, \mathrm{z}=2.29, \mathrm{n}_{\text {adult }}=13, \mathrm{n}_{\text {juvenile }}=10$; MannWhitney $U$ test, one-tailed). A positive correlation between SVL and $Y$ for combined sites is depicted in the scatter plot given in Figure 1. Differences in $Y$ were not significant between adult males from both population sites $\left(0_{\text {Chame }}=0.86 \mathrm{~m} ; \mathrm{sd}_{\text {Chame }}=0.57 ; 0_{\text {PNGOT }}=1.094\right.$ $\left.\mathrm{m} ; \mathrm{sd}_{\mathrm{PNGOT}}=0.84\right)\left(\mathrm{P}=0.3192, \mathrm{z}=0.47, \mathrm{n}_{\text {Chame }}=\right.$ $13, \mathrm{n}_{\mathrm{PNGOT}}=9$; Mann-Whitney U test, onetailed). However, there appeared to be a significant difference in $Y$ between juveniles from different populations $\left(0_{\text {Chame }}=0.33 \mathrm{~m}\right.$; $\mathrm{sd}_{\text {Chame }}=0.35 ; 0_{\text {PNGOT }}=0.08 \mathrm{~m} ; \mathrm{sd}_{\text {PNGOT }}=0.13$ ) $\left(\mathrm{P}=0.0294, \mathrm{z}=1.89, \mathrm{n}_{\text {Chame }}=28, \mathrm{n}_{\mathrm{PNGOT}}=10\right.$; Mann-Whitney U test, one-tailed).

\section{Horizontal perch position}

Study results indicated that adults and juveniles did not differentially utilize nocturnal microhabitats with respect to $X$. Both juvenile and adult $\mathrm{X}$ positions were variable $\left(X_{\text {min-juvenile }}=\right.$ $0.35 \mathrm{~m}, X_{\text {max-juvenile }}=4.6 \mathrm{~m}, 0_{\text {juvenile }}=1.79 \mathrm{~m}$, sd juvenile $=1.12 \mathrm{~m} ; X_{\text {min-adult }}=0 \mathrm{~m}, X_{\text {max-adult }}=6.35 \mathrm{~m}$, $0_{\text {adult }}^{\text {juvenile }}=1.25 \mathrm{~m}, \mathrm{sd}_{\text {adult }}^{\text {min-adult }}=1.10 \mathrm{~m}$; data from pooled sites). An analysis of variance of $X$ showed no difference between juveniles and adults exists ( $P$ $=<0.0001, \mathrm{~F}=-2.2596, \mathrm{n}_{\text {adult }}=22, \mathrm{n}_{\text {juvenile }}=38$; ANOVA; data from pooled sites).

\section{Total distance tracked}

This study determined that subjects were capable of being followed to a maximum TDT of $16.65 \mathrm{~m}$ with fluorescent pigments in streamside 


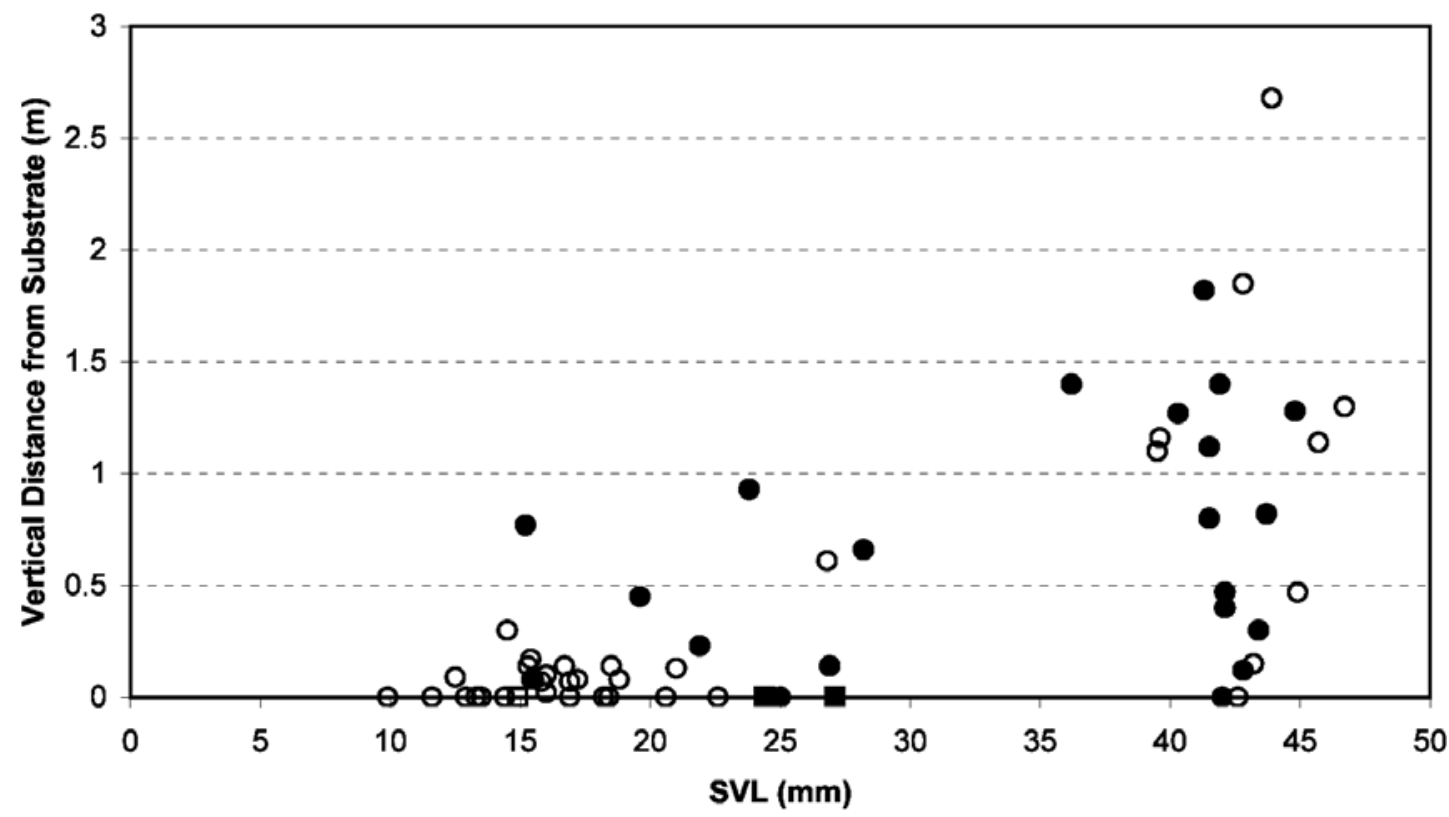

Figure 1 - XY scatter plot showing correlation between snout-vent length (SVL) and vertical distance from substrate $(Y)$. Individuals represented by markers: open (General Omar Torrijos National Park) and solid (Chame River); circle (individual above ground) and square (below ground).

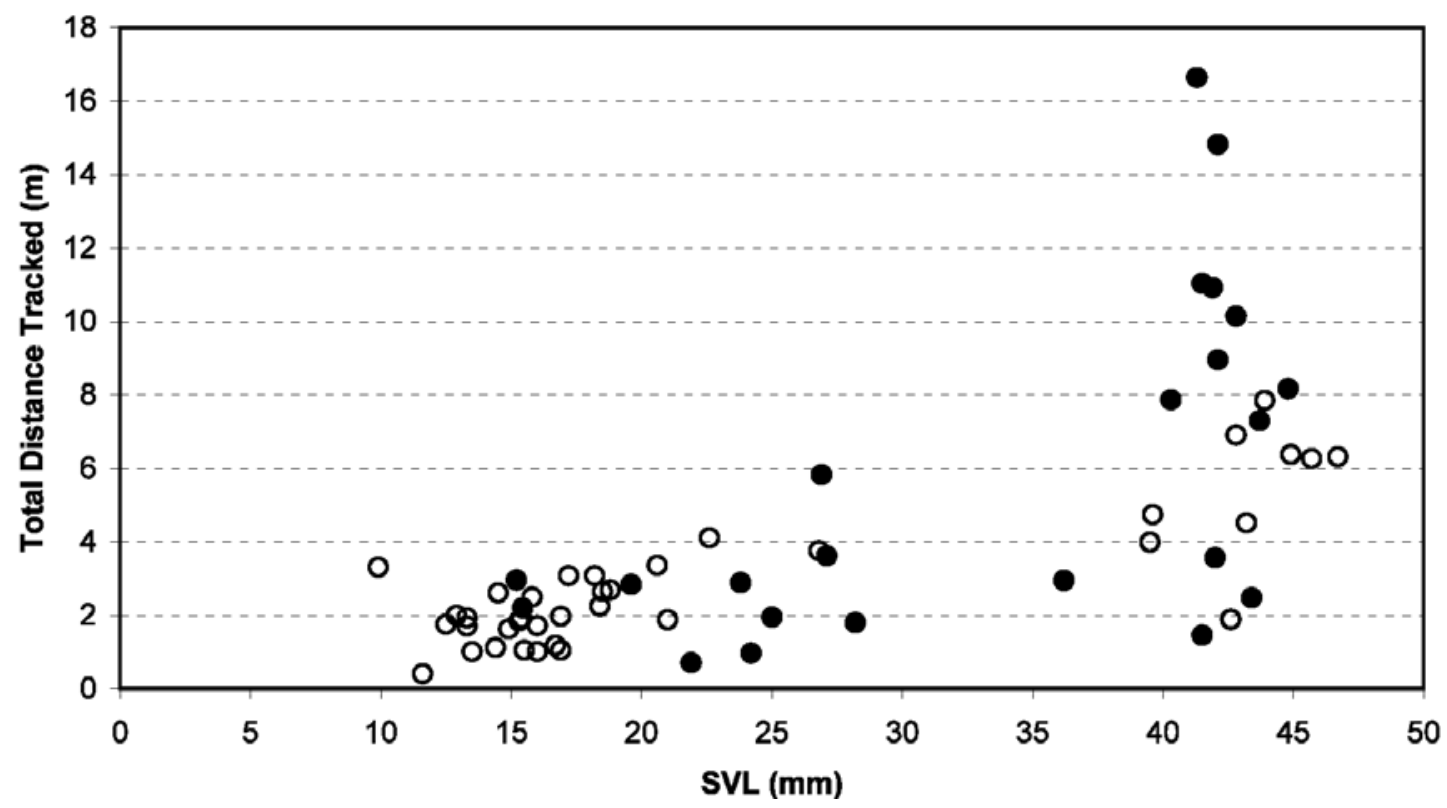

Figure 2 - XY scatter plot showing correlation between snout-vent length (SVL) and total distance tracked (TDT). Individuals represented by circular markers: open (General Omar Torrijos National Park) and solid (Chame River). 
tropical rain forest habitat. TDT was significantly longer in adult males $(0=7.06 \mathrm{~m}$; $\mathrm{sd}=3.96)$ than in juveniles $(0=2.22 \mathrm{~m}$; $\mathrm{sd}=$ 1.09) $\left(\mathrm{P}=<0.0001, \mathrm{z}=5.13, \mathrm{n}_{\text {adult }}=22, \mathrm{n}_{\text {juvenile }}=\right.$ 38; Mann-Whitney U test, one-tailed; data for pooled sites). Within each population, detected differences in TDT were significant at PNGOT $\left(0_{\text {juvenile }}=2.09 \mathrm{~m}, \mathrm{sd}_{\text {juvenile }}=0.92 \mathrm{~m} ; 0_{\text {adult }}=5.43\right.$ $\left.\mathrm{m}, \mathrm{sd}_{\text {adult }}=1.82 \mathrm{~m}\right)\left(\mathrm{P}=0.0001, \mathrm{z}=3.88, \mathrm{n}_{\text {adult }}=\right.$ 9, $\mathrm{n}_{\text {juvenile }}=28$; Mann-Whitney U test, one-tailed) and at Chame $\left(0_{\text {juvenile }}=2.58 \mathrm{~m}\right.$, sd ${ }_{\text {juvenile }}=1.46$ $\left.\mathrm{m} ; 0_{\text {adult }}=8.18 \mathrm{~m}, \mathrm{sd}_{\text {adult }}=4.68 \mathrm{~m}\right)(\mathrm{P}=0.002, \mathrm{z}$ $=2.88, \mathrm{n}_{\text {adult }}=13, \mathrm{n}_{\text {juvenile }}=10$; Mann-Whitney $\mathrm{U}$ test, one-tailed). A positive correlation between SVL and TDT for combined sites is depicted in the scatter plot given in Figure 2. There was also a significant difference in TDT between the two populations $\left(0_{\text {Chame }}=5.74 \mathrm{~m}\right.$; $\mathrm{sd}_{\text {Chame }}=4.57 \mathrm{~m}$; $\left.0_{\text {PNGOT }}=2.90 \mathrm{~m} ; \mathrm{sd}_{\mathrm{PNGOT}}=1.86\right)(\mathrm{P}=<0.0084, \mathrm{z}$ $=2.39, \mathrm{n}_{\text {Chame }}=23, \mathrm{n}_{\mathrm{PNGOT}}=37$; Mann-Whitney $\mathrm{U}$ test, one-tailed). This likely was due to having a juvenile constituency of $75.65 \%$ at the PNGOT sample compared to $38.46 \%$ of Chame. Lastly, there exists a significant correlation between $Y$ and TDT for pooled data $(\mathrm{P}=<$ $0.0001, \mathrm{t}=-8.81, \mathrm{n}_{\text {pooled }}$; paired $\mathrm{t}$-Test for Correlated Samples, one tailed).

\section{Pathways to nocturnal positions}

In this study we found that movement distance from the release site to the nocturnal perch positions in adult males varied dramatically, but generally involved finding the base of a woody plant (e.g. shrub or liana) and climbing to a leaf, leaf axil, or branch that was away from the plant's main trunk. Occasionally herbaceous vines were used. Large ferns were also used as perch sites for adults, with the tips of fronds being primarily used. Rarely were adults found at the base of branches or leaves. Juveniles generally took their nocturnal position in rock crevices or on the ends of small fern fronds or shrubs. The riparian habitat at each study site has potentially climbable herbaceous and woody vegetation from ground level to approximately $25 \mathrm{~m}$ high that, aside from height, could have served as suitable perching sites.

\section{Discussion}

Some of the statistical differences detected between juveniles from each study population, with respect to $Y$, might be explained by the disparate sizes between juveniles from the two populations, genetic (ESU) differences, or small sample sizes (see Figures). Nonetheless, a clear trend exists for adult male A. zeteki to perch significantly higher than juveniles in both pooled and unpooled data sets. Also, the statistically significant difference in TDT between populations might be explained by differences in the age cohort constituency (sample size) within populations and may not necessarily represent actual differences between populations. Lastly, the strong correlation between $Y$ and TDT in this study may attest to the fact that individuals that climb higher at night move further to do so than those that stay lower to the ground. TDT was measured in this study in large part to detect and quantify the complexity of paths taken to nocturnal roosting positions as well as to determine the viability of fluorescent pigment tracking for this species. Although statistical differences were not detected, $X$ was measured specifically to gauge preferences with respect to the primary water source.

The information provided in this study is intended to help conservation efforts in two ways. The first application is that nighttime stream surveys by national park authorities can be better completed by knowing the range in perch heights for adults and juveniles. Second, this information will help zoos and aquariums that currently hold living $A$. zeteki in their collections for captive breeding. It is anticipated that information of this nature would assist breeding professionals in arranging enclosures in ways that might reduce stress on captive animals and potentially increase reproductive success and output. 
The benefits of using fluorescent pigment tracking in this study were surprising. This technique allowed us to track the actual paths chosen by individual animals. Paths taken to final roosting destinations were complex for adult males, involving trunk, branch, and vine climbing, yet were generally uncomplicated and restrictive for juveniles which generally remained near the ground. In addition to microhabitat utilization, another advantage afforded by this technique is its resilience against light to moderate rainfall. In numerous cases of moderate rainfall, the investigators set out to return to sites expecting a complete loss of pigment tracks, yet found most intact. Four juveniles and six adult males (not included in tracking data sets) were pigmented and had their tracks removed by heavy rains. Yet, in some cases, pigments could withstand brief distances of swimming by the subject. The success rate for tracking this species with fluorescent pigments in this study was 60 of 70 total attempts (85.7\%). Pigment use was most effective in dry conditions, yet surprisingly suitable in the tropical rain forests and cloud forests in which this species resides.

Lastly, the reality that adult males nocturnally perch significantly higher than juveniles possibly may be adaptive for many reasons. One possible impetus to drive adult males to climb vegetation at night, as opposed to burrowing, hiding in rock crevices, and/or maintaining daytime position, could be due to shifting predator detection strategies. It was evident that a full size range of perches was available at all heights for both juveniles and adults; likewise for crevice sizes on the ground. Anti-predator vigilance would largely be visual during daytime, whereas perching upon vegetation at night might allow the tactile sensation of an approaching predator via the movement of the perch branch. This may be important for adults that cannot find hiding places that are unreachable by predators. Presumably, this would not be a problem for substantially smaller juveniles. Potential nocturnal stream dwelling predators such as Liophis epinephalus (Reptilia, Colubridae), are known to be capable of metabolizing key skin toxins in Central American Atelopus (Shindelman et al. 1969, Brown et al. 1977, Daly et al. 1987, Pounds 2000, Yotsu-Yamashita et al. 2004). Predation of adult A. zeteki by $L$. epinephalus has been witnessed firsthand by two of us (EJGR and EDL). Changing location based on a shift in sensory cues to improve predator vigilance from day to night might be the most logical explanation.

\section{Acknowledgements}

This work was undertaken as part of the Proyecto Rana Dorada (Project Golden Frog) conservation initiative and in part was funded by grants from the American Zoo and Aquarium Association's Disney Conservation Endowment Fund, Lee University Faculty Scholarship grants (EDL), and by the Garden Clubs of America (SAS). Special thanks are given to B. Lewis, A. Wisnieski, N. Ellis, and E. Kiester for their assistance in refinement of the technique. Likewise we appreciate M. Freake, J. Sander, and K. Terry for assisting in taking measurements. We thank G. Diehl for the information on track persistence with respect to rainfall. We also are indebted to G. Diehl and K. Larson for reviews of earlier manuscripts. Animal care protocol review was provided by Lee University. Finally, we thank La Autoridad Nacional del Ambiente for providing permits for this work.

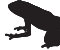

\section{References}

Brown, G. B., Y. H. Kim, H. Küntzel, H. S. Mosher, G. J. Fuhrman, and F. A. Fuhrman. 1977. Chemistry and pharmacology of skin toxins from the frog Atelopus zeteki (Atelopidtoxin: zetekitoxin). Toxicon 15: 115-128.

[CITES] Convention on International Trade in Endangered Species of Wild Fauna and Flora. CITES home page. $<$ http//www.cites.org > Captured on Mar 15, 2006.

Cocroft, R. B., R. W. McDiarmid, A. P. Jaslow, and P. M. 
Ruiz-Carranza. 1990. Vocalizations of eight species of Atelopus (Anura: Bufonidae) with comments on communication in the genus. Copeia 1990: 631-643.

Crump, M. 1986. Homing and site fidelity in a neotropical frog, Atelopus varius (Bufonidae). Copeia 1986: 438444.

Daly, J. W., C. W. Myers and N. Whittaker. 1987. Further classification of skin alkaloids from Neotropical poison frogs (Dendrobatidae), with a general survey of toxic/noxious substances in the amphibian. Toxicon 25: 1023-1095.

Dunn, E. R. 1933. Amphibians and reptiles from El Valle de Anton, Panama. Occasional Papers of the Boston Society of Natural History 8: 65-79.

Johnson, P. T. J. 2006. Amphibian diversity: decimation by disease. Proceedings of the National Academy of Sciences 103: 3011-3012.

Lindquist, E. D. and T. E. Hetherington. 1996. Field studies on visual and acoustic signaling in the "earless" Panamanian golden frog, Atelopus zeteki. Journal of Herpetology 30: 347-354.

Lindquist, E. D. and T. E. Hetherington. 1998a. Tadpole and juveniles of the Panamanian golden frog, Atelopus zeteki (Bufonidae) with information on development of coloration and patterning. Herpetologica 54: 370376.

Lindquist, E. D. and T. E. Hetherington. 1998b. Semaphoring in an earless frog: the origin of a novel visual signal. Animal Cognition 1: 83-87.

Lips, K. R., P. A. Burrows, J. R. Mendelson III, and G. Parra-Olea. 2005. Amphibian declines in Latin America: widespread population declines, extinctions, and impacts. Biotropica 37: 163-165.

Lips, K. R., F. Brem, R. Brenes, J. D. Reeve, R. A. Alford, J. Voyles, C. Carey, L. Livo, A. P. Pessier, and J. P. Collins. 2006. Emerging infectious disease and the loss of biodiversity in a Neotropical amphibian community. Proceedings of the National Academy of Sciences 103: 3165-3170.

Lowry, R. 2004. VassarStats: Web Site for Statistical Computation. <http://faculty.vassar.edu/lowry/ VassarStats.html> Accessed Mar 12, 2006.

Miller, T. 1987. Notes on Central American Atelopus. The Herpetoculturist 1: 25-28.

Pounds, J. A. 2000. Amphibians and reptiles. Pp. 149177 in N. M. Nadkarni and N. T. Wheelwright (eds.), Monteverde: Ecology and Conservation of a Tropical Cloud Forest. New York. Oxford University Press.

Pounds, J. A., M. R. Bustamante, L. A. Coloma, J. A. Consuegra, M. P. L. Fogden, P. N. Foster, E. La Marca, K. L. Masters, A. Merino-Viteri, R. Puschendorf, S. R. Ron, G. A. Sánchez-Azofeifa, C. J. Still, and B. E. Young. 2006. Widespread amphibian extinctions from epidemic disease driven by global warming. Nature 439: 161-167.

Savage, J. M. 1972. The harlequin frogs, genus Atelopus, of Costa Rica and western Panama. Herpetologica 28: 77-94.

Shindelman, J., H. S. Mosher and F. A. Fuhrman. 1969. Atelopidtoxin from the Panamanian frog, Atelopus zeteki. Toxicon 7: 315-319.

Yotsu-Yamashita, M., Y. H. Kim, S. C. Dudley, Jr., G. Choudhary, A. Pfahnl, Y. Oshima,and J. Daly. 2004. The structure of zetekitoxin $\mathrm{AB}$, a saxitoxin analog from the Panamanian golden frog, Atelopus zeteki: a potent sodium channel blocker. Proceedings of the National Academy of Sciences 101: 4346-4351.

Zippel, K. C., R. Ibáñez D., E. D. Lindquist, C. L. Richards, C. Jaramillo, E. J. Griffith. 2007. Implicaciones en la conservación de las ranas doradas de $\mathrm{Pa}$ namá, asociadas con su revisión taxonómica. Herpetotrópicos 3: 29-39. 